\title{
Hubungan Dukungan Suami Dengan Keberhasilan Pemberian ASI Eksklusif Pada Ibu Bekerja
}

\author{
Ratna Ariesta Dwi Andriani, Uke Maharani Dewi \\ Universitas Nahdlatul Ulama Surabaya \\ ratnariesta@unusa.ac.id
}

\begin{abstract}
Abstrak
Tingginya Angka Kematian Bayi (AKB), salah satunya disebabkan oleh kejadian diare. Diare yang disebabkan karena buruknya pemberian makanan dalam enam bulan pertama kehidupan bayi. Pemberian nutrisi yang baik sangat mempengaruhi proses tumbuh kembang bayi. Nutrisi yang paling utama bagi bayi usia 0 sampai dengan 6 bulan adalah Air Susu Ibu (ASI). Kandungan nutrisi yang terdapat didalam ASI sangat sesuai untuk kebutuhan bayi. Di Jawa Timur, pemberian ASI eksklusif angka cakupannya masih kurang dari target. Pada tahun 2010, pemberian ASI eksklusif ditargetkan sebesar $80 \%$, namun capaiannya masih berada jauh dari target yaitu sebesar $30,72 \%$. Tidak adanya dukungan dari keluarga terutama suami, menjadi alasan yang banyak dikemukakan oleh ibu. Tujuan dari penelitian ini adalah untuk menganalisis hubungan antara dukungan suami dengan keberhasilan ibu bekerja dalam memberikan ASI eksklusif kepada bayinya. Teknik sampling dalam penelitian ini menggunakan purposive sampling. Pengambilan data menggunakan kuesioner. Kemudian data yang diperoleh dianalisis menggunakan chi square. Hasil dari penelitian ini berdasarkan uji chi square menyatakan nilai Pvalue yaitu 0,001 $<0,05$ ini artinya terdapat hubungan antara dukungan suami dengan keberhasilan ibu bekerja dalam memberikan ASI eksklusif.
\end{abstract}

Kata kunci : Dukungan suami, Menyusui, ASI eksklusif

\section{Abstract}

The high infant mortality rate (IMR), one of which is caused by the incidence of diarrhea. Diarrhea caused by poor feeding in the first six months of a baby's life. Providing good nutrition greatly affects the baby's growth and development process. The most important nutrition for infants aged 0 to 6 months is breast milk (ASI). The nutritional content contained in breast milk is very suitable for the needs of the baby. In East Java, the coverage of exclusive breastfeeding is still less than the target. In 2010, exclusive breastfeeding is targeted at $80 \%$, but the achievement is still far from the target of $30.72 \%$. The absence of support from the family, especially the husband, is the reason many mothers put forward. The purpose of this study was to analyze the relationship between husband's support and the success of working mothers in providing exclusive breastfeeding to their babies. The sampling technique in this study used purposive sampling. Collecting data using a questionnaire. Then the data obtained were analyzed using chi square. The results of this study based on the chi square test stated that the $P$ value was $0.001<$ 0.05 , this means that there is a relationship between husband's support and the success of working mothers in providing exclusive breastfeeding.

Keywords : partner support, breastfeeding, exclusive breastfeeding

http://ejournal.urindo.ac.id/index.php/kesehatan

Article History :

Sumbitted 03 Juni 2021, Accepted 29 Juni 2021, Published 30 Juni 2021 


\section{PENDAHULUAN}

Salah satu indikator yang dapat dilihat untuk menentukan status kesehatan suatu Negara adalah Angka Kematian Ibu (AKI) dan Angka Kematian Bayi (AKB). Infeksi saluran pernafasan dan diare menjadi penyebab utama dari kematian bayi. Buruknya pemberian makanan diusia 6 bulan pertama kehidupan bayi menjadi salah satu penyebab terjadinya diare (Gupta, 2013).

Pertumbuhan dan perkembangan yang sehat bagi bayi sangat dipengaruhi oleh pemenuhan nutrisi (Ramaiah, 2006). Pemberian Air Susu Ibu (ASI) dapat memenuhi nutrisi yang sehat dan memadai bagi bayi baik dari segi kualitas maupun kuantitasnya. Kebutuhan nutrisi yang utama pada bayi usia 0 sampai 6 bulan yaitu dengan memberikan ASI, hal ini dikarenakan komposisi dari ASI sangat sesuai dengan kebutuhan bayi (Hidayat, 2009).

Tumbuh kembang dan keberlangsungan hidup bayi dan anak usia dibawah dua tahun (baduta) sangat dipengaruhi oleh pemberian nutrisi yang tepat dan optimal. Pemberian makanan yang tepat menurut Global Strategy on Infant and Young Child Feeding, adalah dengan cara sesegera mungkin susui bayi setelah lahir, berikan hanya ASi saja tanpa bahan makanan tambahan apapun sampai bayi berumur 6 bulan, berikan makanan tambahan sebagai pendamping ASI secara tepat dan adekuat dimulai sejak usia bayi 6 bulan, serta lanjutkan pemberian ASI sampai anak berumur 2 tahun atau lebih (WHO, 2002).
Semakin bertambahnya usia bayi, maka prosentase pemberian ASI eksklusif akan menurun. 48,7\% pada bayi usia 0 sampai 1 bulan, 42,2\% pada bayi usia 2 sampai 3 bulan menurun menjadi $42,2 \%$ dan semakin akan semakin menurun menjadi 36 , $6 \%$ pada bayi berusia 4 sampai 5 bulan dan 30, 2\% pada bayi usia 6 bulan (Riskesdas, 2013). Menurut data dari Dinas Kesehatan Provinsi Jawa Timur tahun 2010, angka cakupan ASI eksklusif pada tahun 2010 masih berada jauh dibawah target $80 \%$ yaitu hanya sebesar $30,72 \%$.

Adanya dukungan dari suami dan orangtua menjadi faktor penguat bagi ibu dalam memberikan ASI eksklusif pada bayi. Namun sayangnya masih banyak ibu yang mengungkapkan bahwa mereka tidak mendapatkan dukungan dari keluarganya dalam memberikan ASi eksklusif. Padahal kita semua tahu bahwa suksesnya seorang ibu dalam memberikan ASI eksklusif merupakan tanggung jawab keluarga termasuk ayah, nenek, kakek dan semua orang yang nantinya akan terlibat langsung dalam mengurus bayi (Roesli, 2008).

Pada kenyataannya, di masyarakat masih banyak anggapan bahwa menyusui hanya sebatas urusan ibu dan bayinya saja. Masyarakat tidak menyadari bahwa dukungan suami menjadi faktor pendukung utama dalam keberhasilan pemberian ASi eksklusif. Seorang suami dianggap sebagai orang terdekat dan sangat berpengaruh kepada ibu untuk dapat secara maksimal memberikan ASI eksklusif pada bayinya. Dukungan dari suami dalam pemberian 
ASI eksklusif juga dapat menghilangkan kekhawatiran seorang istri akan perubahan bentuk payudara yang dianggap tidak menarik lagi pasca menyusui (Proverawati, 2010). Penelitian kali ini bertujuan untuk melakukan analisis hubungan antara dukungan suami dengan keberhasilan ibu bekerja dalam memberikan ASi eksklusif pada bayinya, sesuai dengan teori yang dikemukakan oleh Roesli (2012), bahwa tercapainya pemberian ASI secara eksklusif diperlukan dukungan dari suami.

\section{METODE}

Penelitian ini merupakan penelitian observasional analitik dengan rancang bangun penelitian cross sectional. Pada penelitian ini, variabel yang diteliti adalah dukungan suami dan keberhasilan pemberian ASI eksklusif pada ibu bekerja. Uji korelasi chi square digunakan untuk menganalisis hubngan anatar variable bebas dan terikat. Sampel yang digunakan dalam penelitian ini adalah ibu bekerja dan menyusui yang memiliki bayi usia 6 bulan sampai dengan 24 bulan.

\section{HASIL DAN PEMBAHASAN}

1. Analisa Univariat

Tabel 1.1 Distribusi Frekuensi Dukungan Suami Tahun 2020

\begin{tabular}{cccc}
\hline No & $\begin{array}{c}\text { Dukungan } \\
\text { Suami }\end{array}$ & Frekuensi & $\begin{array}{c}\text { Prosentase } \\
\text { (\%) }\end{array}$ \\
\hline $\mathbf{1}$ & Baik & 35 & 67,3 \\
$\mathbf{2}$ & Kurang & 17 & 32,7 \\
& Total & 52 & 100 \\
\hline
\end{tabular}

Tabel 1.1 menunjukkan sebagian besar suami memberikan dukungan yang baik, yaitu sebesar $67,3 \%$.

Tabel 1.2 Distribusi Frekuensi Pemberian ASI Eksklusif Tahun 2020

\begin{tabular}{cccc}
\hline No & $\begin{array}{c}\text { Pemberian } \\
\text { ASI }\end{array}$ & Frekuensi & $\begin{array}{c}\text { Prosentase } \\
\text { (\%) }\end{array}$ \\
& Eksklusif & & \\
\hline $\mathbf{1}$ & Berhasil & 23 & 44,2 \\
$\mathbf{2}$ & Tidak & 29 & 55,8 \\
& Berhasil & & \\
& Total & 52 & 100
\end{tabular}

Tabel 1.2 menunjukkan sebagian besar ibu tidak berhasil dalam memberikan ASI eksklusif, yaitu sebesar 55,8\%.

2. Analisa Bivariat

Tabel 2.1 Distribusi Silang Dukungan Suami dengan Keberhasilan ASI Eksklusif Tahun 2020

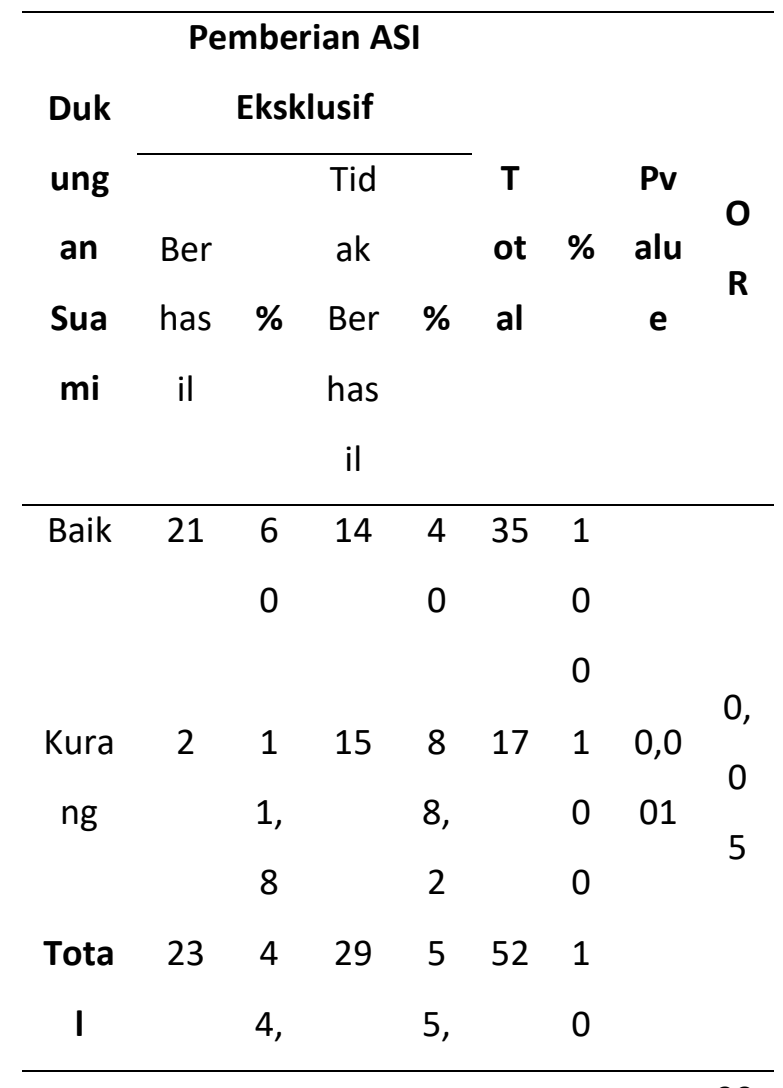




\begin{tabular}{llll}
\hline 2 & 8 & 0
\end{tabular}

Tabel 2.1 berdasarkan hasil uji chi square menyatakan nilai Pvalue yaitu 0,001<0,05. maka disimpulkan terdapat hubungan yang bermakna antara Dukungan Suami dengan Keberhasilan Ibu Bekerja dalam Memberikan ASI Eksklusif.

Hasil dari distribusi frekuensi dukungan suami menunjukkan bahwa sebagian besar suami memberikan dukungan yang baik yaitu sebesar 67,3\%. Dukungan suami diharapkan dapat memberikan manfaat atau sebagai pendorong ibu dalam pemberian ASI eksklusif. Dukungan suami merupakan salah satu faktor yang mempengaruhi sikap ibu dalam pemberian ASI eksklusif (Hargi, 2013). Hal ini juga sejalan dengan hasil penelitian Wahyuningsih (2013) yang menunjukkan bahwa ibu yang diberikan dukungan informasional oleh suami cenderung akan memberikan ASI Eksklusif dibandingkan dengan ibu yang tidak mendapatkan dukungan informasional dari suami. Hasil penelitian Ramadani (2010) menyatakan bahwa pentingnya peran suami dalam pemberian ASI eksklusif menharuskannya untuk menjadi sasaran penyuluhan ASI dan didorong untuk berperan aktif mencari informasi agar lebih paham dalam memberikan dukungan.

Pada tabel distribusi frekuensi pemberian ASI eksklusif menunjukkan bahwa sebagian besar ibu tidak berhasil meberikan ASI eksklusif yaitu sebesar 55,8\%. Hasil ini cukup menyedihkan. Hal ini bisa saja terjadi karena tidak adanya dukungan dari suami maupun keluarga. Dalam pasal 128 ayat 2 dan 3 Undang Undang Republik Indonesia Nomor 36 tahun 2009 tentang kesehatan disebutkan bahwa selama pemberian ASI, pihak keluarga, pemerintah daerah dan masyarakat harus mendukung ibu secara penuh dengan penyediaan waktu dan fasilitas khusus bagi ibu yang sedang menyusui (Februhartanty, 2008)

Hasil analisa data dalam penelitian ini menunjukkan adanya hubungan yang bermakna antara Dukungan Suami dengan Keberhasilan Ibu Bekerja dalam Memberikan ASI Eksklusif dengan nilai Pvalue $0,001<0,05$. Peran ayah sangat menentukan keberhasilan proses menyusui karena keikutsertaan ayah dalam memberikan dukungan emosional dan bantuan-bantuan lainnya akan mempengaruhi kkeadaan emosi dan perasaan ibu, yang nantinya juga akan menentukan kelancaran reflek pengeluaran ASI (Roesli, 2000). Hasil penelitian kali ini sejalan dengan hasil penelitian Ramadani (2010) yaitu ibu yang mendapatkan dukungan dari suaminya akan berpeluang dua kali lipat dalam memberikan ASI eksklusif dibandingkan dengan ibu yang kurang mendapatkan dukungan dari suami. Hasil penelitian yang dilakukan oleh Abidjulu (2015), menyatakan bahwa dukungan suami sangat diperlukan untuk tercapainya pemberian ASI eksklusif. Suami haru memberikan kalimat pujian atau pun kata-kata yang dapat memberikan semangat kepada ibu untuk menyusui bayinya. Salah satu dukungan yang bisa diberikan oleh suami kepada ibu menyusui yakni dengan tidak memberikan 
kritik terhadap bentuk tubuh istri.Karena dengan tidak memberikan kritikan maka istri tidak merasa risih dengan bentuk tubuhnya ataupun bentuk payudaranya sehingga kemauan istri untuk memberikan ASI eksklusif tidak berkurang hanya karena disebabkan oleh kritikan yang disampaikan oleh suami.Hasil penelitian memuat pernyataan singkat tentang hasil penelitian. Sedangkan pembahasan berisi diskusi yang menghubungkan dan membandingkan hasil penelitian dengan teori dan hasil penelitian sebelumnya.

\section{KESIMPULAN}

Terdapat hubungan yang signifikan antara dukungan suami dengan keberhasilan ibu bekerja dalam memberikan ASI eksklusif pada bayinya.

\section{PENUTUP}

Peneliti mengucapkan terimakasih kepada seluruh tim dari penelitian ini dan kepada universitas nahdlatul ulama surabaya.

\section{DAFTAR PUSTAKA}

Abidjulu, F. R., Hutagaol, E., \& Kundre, R. 2015. Hubungan dukungan suami dengan kemauan ibu memberikan Asi eksklusif di puskesmas tuminting kecamatan tuminting. Jurnal Keperawatan, 3(1).

Afifah, D.N. 2007. Faktor yang Berperan dalam Kegagalan Praktik Pemberian ASI Eksklusif. Semarang: Eprints UNDIP
Dagun, S. M. (2002). Psikologi Keluarga (Peran Ayah dalam Keluarga). Jakarta: PT Rineka Cipta

Damayanti, Diana. 2010. Asyiknya Minum ASI. Jakarta: PT. Gramedia Pustaka Utama

Dinas Kesehatan Provinsi Jawa Timur. 2010. Profil Kesehatan Provinsi Jawa Timur Tahun 2010. Surabaya: Dinas Kesehatan Provinsi Jawa Timur

Februhartanty Judhiastuty. 2008. Peran Ayah dalam Optimalisasi Praktek Pemberian ASI: Sebuah Studi Di Daerah Urban Jakarta, Disertasi, Universitas Indonesia

Glanz, Karen., et al. 2008. Health Behaviour and Health Education Theory, Research, and Practice. USA: Jossey-Bass

Gupta, A., Padhich, J. P., Suri, S. 2013. How Global Rates Of Exclusive Breastfeeding For The First 6 Months Be Enhanced. ICAN. Vol. 5 (3): 133-140, 2013

Hargi, J. P. 2013. Hubungan dukungan suami dengan sikap ibu dalam pemberian ASI eksklusif di Wilayah Kerja Puskesmas Arjasa Kabupaten Jember. Universitas Jember

Hidayat, A. Aziz Alimul. 2009. Pengantar IImu Keperawatan Anak Buku 1. Jakarta: Salemba Medika

Ingela, S. 1999. The Experience of Social Support in Patients Suffering from Treatment Refractory Depression a Pilot Study Archieve of Psychiatric Nursing. Philadelphia: Lippircot 
Kurniawati, I. 2015. Pengaruh Pengetahuan, Motivasi, dan Dukungan Suami Terhadap Perilaku Pemeriksaan IVA pada Kelompok Wanita Usia Subur di Puskesmas Kedungrejo. Tesis. Surakarta: Program Studi Magister Kedokteran Keluarga Program Pascasarjana Universitas Sebelas Maret

Nugroho, Taufan. 2011. ASI dan Tumor Payudara. Yogyakarta: Nuha Medika Proverawati. 2010. Kapita Selekta ASI dan Menyusui. Yogyakarta: Nuha Medika Ramadani, M., \& Hadi, E. N. 2010. Dukungan Suami Dalam Pemberian Asi Eksklusif Di Wilayah Kerja Puskesmas Air Tawar Kota Padang, Sumatera Barat. Kesmas: National Public Health Journal, 4(6), 269274.

Ramaiah, S. 2006. ASI dan Menyusui. Jakarta: PT Bhuana Ilmu Populer Kelompok Gramedia

Riskesdas. 2013. Riset Kesehatan Dasar: RISKESDAS 2013. Jakarta: Badan
Penelitian dan Pengembangan Kesehatan Kementrian Kesehatan RI

Roesli, U. 2008. Mengenal ASI ekslusif. Jakarta: Pustaka Bunda

Roesli, U. 2012. Inisiasi menyusui dini plus ASI eksklusif. Jakarta: Pustaka Bunda

Sarafino, E.P. and Timothy W.S. 2011. Health Psychology Biopsychosocial Interactions 7th Edition. United States of America: John Wiley \& Sons, Inc

Wahyuningsih, D. 2013. Dukungan Suami dalam Pemberian ASI Eksklusif. Jurnal Keperawatan Maternitas, 1(2)

World Health Organization. 2002. Global strategy for infant and young child feeding. WHA 55/2002/REC/I, annex 2. Geneva: World Health Organization

Yuliarti, N. 2010. Keajaiban ASI: Makanan Terbaik untuk Kesehatan, Kecerdasan dan Kelincahan Si Kecil. Yogyakarta: Andi 